\title{
Personal Skills, Job Satisfaction, And Productivity In Members Of High Performance Teams
}

\author{
Patricia Valdés-Flores, (Email: pvaldes@cetys.net), CETYS Universidad, Tijuana B.C., México \\ Javier Arturo Campos-Rodríguez, (Email: cavatij@gmail.com), CAVA Investigación Psicología Integral, Tijuana B.C., México.
}

\begin{abstract}
The intention of the study is to identify the development of personal skills, as well as the increase of job satisfaction and productivity of the employee, as a result of their participation in high performance teams. Volunteered in the study 139 members of self-managed teams belonging to the Production Area, 39 of Operational Administrative teams, 19 members of Cross-Functional teams and 6 of 6-Sigma Projects, all of them belonging to a company of the Maquiladora Industry in Tijuana, B.C., México. The study indicates that $100 \%$ of the members of the Production Area teams and the Operational Administrative teams developed some personal skills or increased their satisfaction or productivity as a result of their participation in some kind of self-managed team. In Cross-Functional teams members, the changes took place in the $94.3 \%$ of the cases and in the 97\% of the 6-Sigma teams' members. There was also a significant difference found between the results of the four types of self-managed teams studied. This paper provides information to CEOs regarding the importance of the design and the implementation of working programs for selfmanaged teams; these not only will strengthen the employee achievement of a greater satisfaction and productivity, but will also allow them to develop personal skills.
\end{abstract}

Key Words: Self-managed teams, job satisfaction, productivity and personal skills.

\section{INTRODUCTION}

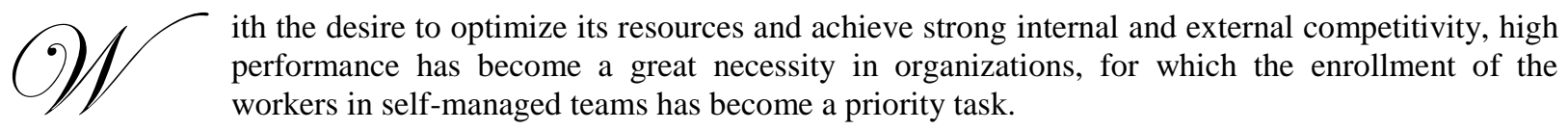

The self-managed teams are made of a small group of people with the power to direct themselves (Ramirez, 2005). They are natural working groups to whom are given considerable autonomy and are asked to control their own behavior and to produce significant results (David and Newstrom, 2003).

The members of self-managed teams plan and program their activities, make decisions, solve problems that affect them and mutually supervise themselves (Robinson, 2004).

For the purposes of this study, self-managed teams will be considered of high performance, in which Parés (2006) expresses "the teams of high performance do not necessarily work more, or are more intelligent than the rest, the main difference consists on being able to organize themselves and deliver exceptional results, given the sum of their strengths and their internal organization".

Moreno-Luzon and Martínez (Benavides Espinosa and Escibá Moreno, 2001), argue that each company will develop the kind of team that reports the largest amount of advantages for the attainment of their objectives. Thus, for the purpose of this paper, four types of self-managed teams will be considered. 
- $\quad$ Production Area teams. Operation working teams, responsible to manage work routines, establishing and negotiating its goals and having autonomy over their processes; they work in improvement projects that impact the results of their mini-businesses.

- Operational Administrative teams. They have the same function than the self-managed production teams but they belong to the administrative areas.

- $\quad$ Cross-Functional teams. Made up by personnel from diverse functional areas and have the responsibility to carry out improvement projects in the diverse organization processes.

- $\quad$ 6-Sigma teams. Made up from people of diverse areas and have the responsibility to improve the processes through specialized tools.

Both job satisfaction (Dessler, 2001; Mathis and Jackson, 1997) and productivity (Bain, 1992; Garza, 2000) of the employee are topics of great interest for the organizations executives, given the need to maximize the use of their resources in pro of covering their clients' expectations in a satisfactory way.

Davis and Newstrom (2003) and Dessler (2001) describe the job satisfaction as a set of favorable or unfavorable feelings for the employees to perceive their work and that determine the possibility of a major disposition to achieve higher performance, consequently, job satisfaction refers to an individual's general attitude toward his or her job (Robbins, 1998).

On the other hand, the productivity, determined by means of the relationship that exists between what is produced and the goods and the services utilized for production (Hernández, 1994; Schroeder, 1992), is also an important element in the satisfaction process of the clients demands, in the optimum use of resources for this purpose and, therefore, obtaining high performance for the company, which constitutes one of its main objectives (Alvarez, Dominguez, Dominguez, Garcia and Ruiz, 1995).

Given that life in work place is influenced by job satisfaction and productivity (Valdes Flores, 2001; Valdés Flores, Campos Rodríguez and Guzmán Pérez, 2003), factors that make up the reason of being of companies (Ciconne, 1998; Garza, 2000; Siliceo, 1995) and directly related with the personal skills linked to the continuous improvement processes, the aim of this paper is to identify the degree in which these three aspects are impacted as a result of the workers participation in self-managed teams.

For the purpose of the issues previously mentioned, the personal skills will be understood as the self perceived group of abilities required for tasks compliment and abilities to deal with people (Davis and Newstrom, 2003), that contribute to personal growth (McCaskey, 1997).

According to Davis and Newstrom (2003), those organizations that deal with self-managed teams, show significant advantages as greater personnel flexibility, higher levels in organizational commitment and in job satisfaction.

The domestic companies that have done investigation regarding the benefits obtained when their workers participate in self-managed teams or in high performance teams, have not documented their findings. Because of this fact, an instrument has been designed to identify the degree in which this event infers in the development of personal skills, as well as in the increase of satisfaction and productivity of the employee participant in the study, members of a company of the transformation industry in the city of Tijuana, B.C., México.

Is the intention of this paper to contribute to the interests of businessmen, administrators, workers and educators, to strengthen the work of self-managed or high performance teams, stating the benefits that this represents for the productivity of their companies. 


\section{METHOD}

\section{Subjects}

Out of a variable population of 2087 workers involved in some kind of self-managed team at the moment of the study, there was a voluntary participation of 139 members of Production teams, 39 of Operational Administrative teams, 19 of Cross-Functional teams and 6 members of 6-Sigma teams.

The group of volunteers of self-managed Production teams includes $87 \%$ women, $9 \%$ men and $4 \%$ do not manifest gender. 17\% are Elementary School graduates; $28 \%$ are Secondary Education or Commerce graduates; 28\% with High School degree; 6\% with Trade School studies; $4 \%$ are University students, $2 \%$ have a Masters degree and $14 \%$ do not show academic information.

Among the volunteers of the self-managed Operational Administrative teams we found a $38 \%$ of women participation, a 59\% of men and 3\% did not state gender. 2\% are Elementary School graduates; 3\% are Secondary Education or Commerce graduates; $8 \%$ with High School degree; $10 \%$ with Trade School degree; $13 \%$ University students; $56 \%$ have a University degree and an $8 \%$ have a Masters degree.

The members of the Cross-Functional self-managed teams are represented by $42 \%$ women and $58 \%$ of men. 15\% are Secondary Education or Commerce graduates; $11 \%$ with Trade School degree; $21 \%$ are University students and $53 \%$ have a University degree.

The 6-Sigma self-managed team volunteers group includes 33\% women and $67 \%$ men. $17 \%$ are University student and $83 \%$ have a University degree.

\section{Instrument}

A three respond options printed questionnaire in a 35 item Likert scale was applied; this allows measuring the level of development of personal skills such: achievement capability, tolerance, decision making, communication, leadership and self-esteem, and the increase of job satisfaction and productivity of the workers as a result of their participation in high performance teams (self-managed).

\section{Procedure}

The final instrument was designed out of 60 original items, aimed at the identification of the personal skills related to the achievement, tolerance, self-esteem, decision making, communication and leadership, as well as the satisfaction and productivity of the workers.

The original questionnaire was given to a group of 15 judges, supervisors or department's leaders, as well as subordinates, who were chosen by chance. The judges analyzed the issues at hand and the applicability of the reagents and made some remarks on the subject.

By means of the judges opinion, it was determined a final number of 35 items oriented to identify the mentioned aspects, achieving, therefore, the instrument's validation.

With the purpose of obtaining the instrument reliability through the cronbach alpha coefficient procedure using the Statistics Package for Social Science (SPSS), 30 individuals answered to the pilot questionnaire.

There was found a .94 reliability rate with a .06 variance of error for the instrument.

Volunteers from a company of the transformation industry, in the city of Tijuana, B.C., answered to the questionnaire, to whom it was explained the instructions and were asked to clarify any existing doubt during the filling in process. 
For the inferential data analysis, $\mathrm{X}^{2}$ test was applied.

\section{RESULTS}

It was found that $100 \%$ of the members of the Production teams and the Operational Administrative teams developed some skill or increased their satisfaction or productivity as a result of their participation in some selfmanaged team. In the case of members from the Cross- functional teams, the changes happened in the $94.3 \%$ of the cases and in the $97 \%$ of the 6-Sigma teams' members.

In general, the participants of the four groups subjected to study, refer the development of some personal skills and manifested a greater satisfaction and productivity as a result of their participation in self-managed teams. The participants that showed a greater development were the members of the 6-Sigma teams, in a $46 \%$. The participants that showed the least amount of development were the members of the Cross-Functional teams, in a $36 \%$, in contrast with a $41 \%$ of the members of the Production teams and the $38 \%$ of the members of the Operational Administrative teams.

The skills in which the members showed a greater development were the ones related to promote all the team members to help in problem solving, maintaining the cohesion of team members, reconciling the members interests and also to contribute ideas to improve the company's processes; while the ones that showed the least development were the ones related to have the firm will to reach success in what is done and decision making in order to develop new projects in their personal lives.

The members of Production teams showed a greater development in the skills: to maintaining the union of team members, reconciling the members interests (56\%) and to openly dialog with people that have criticized their work (53\%); the skills with the least development in this group were: to have the firm will to reach success in what they do (12\%), accept criticism (25\%) and aim to finish what they start (27\%).

The skills with greatest amount of development in the members of the Operational Administrative teams were: to promote the members of the team to help problem solving $(69 \%)$, to promote ideas to improve the company's processes $(67 \%)$ and to develop new communication skills $(67 \%)$; the skills to accept the superiors' opinion $(13 \%)$ and to forgive themselves when they are wrong $(15 \%)$ were the ones that shown the least development.

The members of the Cross-Functional teams referred to have developed with a greater intensity the skills: to contribute ideas for the improving of the team's processes (79\%) and to maintain the cohesion of team members, reconciling the members interests( $68 \%$ ); they manifested no growth in the skills: to have the firm will to reach success in what they do and to forgive themselves when they are wrong; following the skills of decision making for the development of new projects for their personal lives, with the least development (5\%).

The skills that show a greater development in the 6-Sigma teams' participants were: to promote that all of the team members help in problem solving (100\%) and maintaining the cohesion of team members, reconciling the members interests $(68 \%)$; the ones that showed no development at all were: the ability to have a firm will to reach success in what they do, followed by what they showed to have developed with the least intensity, all of them in the $16 \%$ of the participants: to help their team and the company to achieve its goals with success, to execute with pleasure the assigned task, to look for their own growth in their job, to make decisions for the development of new projects in their personal lives, and to communicate their ideas with their coworkers and superiors with no fear.

Even the relative arithmetical difference in global increase in job satisfaction (29\%) and productivity (32\%) items; the Productions teams' members showed a greater increase in job satisfaction (46\%) than the rest of the teams' members, while, the $50 \%$ of the 6 -Sigma teams' members showed a greater increase in productivity than the members of the rest of the teams. 
The statistical analysis reflects a significant difference $(\mathrm{p}=.01)$ between the results of the four types of selfmanaged teams analyzed.

\section{DISCUSSION AND CONCLUSIONS}

We emphasize in the instrument validation, which manifests the fact that the employee participation in selfmanaged teams has favored the development of personal skills such as achievement capability, tolerance, decision making, communication, leadership, and self-esteem, and the increase of job satisfaction and productivity of the workers enrolled.

Considering the absence of similar investigations' evidences, it has not possible to contrast the findings of the present study, nevertheless, Mc. Caskey (Franco and Reyes, 2003) and Kaisen Group (2007) proposals are confirmed; they reported that the performance of self-managed teams reflects an improvement in productivity, satisfaction and personal growth.

Even though the ability to make decisions for the development of new projects in personal lives was one of the least developed skills among the participants, according with Sanchez, Calzada y Aguilera (2004), who argue that self-managed teams not only contribute to improve the operational performance, but also with the people's performance. The rest of the analyzed skills, are also linked to the individuals' personal live.

Kennetthe Cloke and Joan Goldsmith (Ayup and De la Garza, 2004), pointed out that successful teams have skills such as: self-direction, communication, leadership, problem solving and itself enjoyment, similar to the ones analyzed and developed or improved by the study's volunteers.

An affinity is also found with the reasoning of Fernandez and Winter (2003), who states some high performance teams' characteristics such as: support and listen, respect for differences, open confrontation and communication of conflicts, leadership, decision making, security, initiative and influencing communication, similar to the ones identified as developed by the study's participants.

It is important to point out that the skills in which the teams demonstrated the least development are related to the participants personal live, while the ones with a greater development are related to the integration of the team members, problem solving and to contribute ideas to company's improvement, which determines the degree of loyalty and commitment of the participants to the company they work for, more than themselves; this could be strongly related to the fact that they are part of a high performance team.

The outcomes of this study provide information to businessmen, presidents and faculty regarding the importance of the integration of self-managed or high performance teams, for organizational development as well as personal development; this also allows CEO's to verify if their techniques and work processes must be improved for

job satisfaction and productivity growth, as well as encouraging further investigation and application in a range of development of personal skills and high performance teams in the organizational context.

\section{REFERENCES}

1. Alvarez, G., M. J., Domínguez, M. J. A., Domínguez, M. M. A., García, G. S. y Ruíz, J. A. (1995). Dirección de Operaciones: Aspectos estratégicos en la producción y los servicios. Madrid: McGraw-Hill.

2. Ayup González, J. y De la Garza Ramos, M. I. (2004). Interculturalidad: Instrumento de gestión en los negocios. Retrieved September 20, 2006 from http://www.alafec.unam.mx/asam_cuba/ponencias/negint/negint04.doc

3. Bain, D. (1992). Productividad. México: McGraw-Hill.

4. Benavides Espinoza, M. M. y Escribá Moreno, M. A. (2001). La dirección y el trabajo en equipo como impulsores del aprendizaje organizativo. Revista de dirección, organización y administración de empresas, $\mathrm{N}^{\circ}$ 26, pp. 34-41. Retrieved September 21, 2006 from http://www.cepade.es/Ademas/fr_pdf.asp?num=26\&artic=3 
5. Ciconne, J. A. (1998). Un mal clima en la organización afecta la productividad. CICLOS La Revista del Noroeste, Vol. 14, año 2, p.25.

6. Davis, K. y Newstrom, J. W. (2003). Comportamiento Humano en el Trabajo. México: McGraw-Hill.

7. $\quad$ Dessler, G. (2001). Administración de Personal. México: Prentice Hall.

8. Fernández, I. y Winter, T (2003.) Equipos De Alto Desempeño: Un Gran Desafío Para Las Organizaciones. Serie Azul Psicología y Empresa. Cuaderno de trabajo $\mathrm{N}^{\circ}$ 4. Noviembre.

9. Franco G., C. A. y Reyes S., A. J. (2003). Los Equipos De Trabajo Como Estrategia De Diferenciación. Estudios Gerenciales, abril-junio, número 087 pp. 13-25.

10. Garza Treviño, J. G. (2000). Administración Contemporánea. México: McGraw-Hill.

11. Hernández, R. S. (1994). Introducción a la Administración. México: McGraw-Hill.

12. McCaskey, M. B. (1997) Framework for Analyzing Work Groups. Harvard Business School. pp. 1-18.

13. Mathis, R. L. y Jackson, J. H. (1997). Human Resource Management. Minneapolis/St. Paul: West Publishing Company.

14. Parés Arce, G. R. (2006). Construcción de equipos de trabajo de alto desempeño. Retrieved September 29, 2006 from http://www.gestiopolis.com/canales6/rrhh/como-hacer-equipos-de-trabajo.htm

15. Ramírez, M. A. (2005). Equipos de Trabajo. México: CESUN Universidad \& DDO Producciones.

16. Robbins, S. P. (2004). Comportamiento Organizacional. México: Pearson/Prentice Hall.

17. Robbins, S. P. (1998). Organizational Behavior. New Jersey: Prentice Hall.

18. Sánchez Callís, I., Calzada Linares, L. y Aguilera Caporte, L. I. (2004). Los equipos autodirigidos: Novedoso instrumento para la gestión del conocimiento en organizaciones emergentes. Retrieved October 17, 2006 from http://www.congreso-info.cu/UserFiles/File/Info2004/Ponencias/184.pdf

19. Schroeder, R. G. (1992). Administración de Operaciones. México: McGraw-Hill.

20. Siliceo, A. (1995). Liderazgo para la productividad en México. México: Limusa.

21. Valdés Flores, P. (2001). La percepción de supervisores y subordinados respecto a la relación del liderazgo con la satisfacción en el trabajo y la productividad. Unpublished doctoral dissertation. CETYS Universidad, B.C., México.

22. Valdés Flores, P., Campos Rodríguez, J. A. y Guzmán Pérez, J. M. (2003, julio-diciembre). La satisfacción laboral y la productividad: Percepción de supervisores y subordinados. Enseñanza e Investigación en Psicología, 8, (2), pp. 325-334. 